\title{
Efficacy of Ivermectin-Based Drugs against Ectoparasites in Broiler Chickens
}

\author{
Gulnara B. Arisova \\ All-Russian Scientific Research Institute of Fundamental and Applied Parasitology of Animals and Plants named after K.I. Skryabin - Branch of the \\ Federal State Budget Scientific Institution «Federal Scientific Center - All-Russian Scientific Research Institute of Experimental Veterenari Medicina \\ K.I. Skryabin and Y.R. Kovalenko the Russian Academy of Sciences», B. Cheremushkinskaya Street 28, 117218 Moscow, Russia. \\ *Corresponding author's Email: g.arisova@vniigis.ru; (D) ORCiD: 0000-0002-6918-4421
}

\begin{abstract}
This research aimed to study the efficacy of two different ivermectin-based drugs against ectoparasites of chickens. In total 1200 Highsex brown chickens aged 1-1.5 years were examined to determine the prevalence of ectoparasites among chickens. The diagnosis of ectoparasites in chickens was established using clinical and entomological methods. For studying drug efficacy, 20 chickens were selected and divided into two groups (experimental and control) of 10 birds each according to the principle of analogs. A prepared ivermectin-based drug consisting of active substance ivermectin and the auxiliary substances including jojoba Resplanta, diethylene glycol monoethyl ether, Tween-80, benzyl alcohol, and purified water, was administered to the experimental group at a dose of 0.4 $\mathrm{ml} / \mathrm{L}$ of drinking water $(400 \mu \mathrm{g}$ ivermectin per $1 \mathrm{~kg}$ of body weight) twice with a 24-hour interval. The treatment was repeated after 14 days. The control group was administered another drug based on ivermectin in the same dose and manner as the drug given in the experimental group. The efficacy of the drugs was determined by counting the number of ectoparasites per chicken before and after treatment. The clinical condition of the birds was monitored from day 1 to day 28 of the experiment. To evaluate the physiological state of chickens, blood and biochemical tests were performed on day 28 of the experiment. The results revealed that the prevalence of infection with Menacanthus stramineus, Menopon gallinae, and Dermanyssus gallinae in chickens was 34.5\%, 21.5\%, and 12\%, respectively. The number of parasites/chicken after treatment between the experimental and the control group was significantly different. The efficacy of the drugs against ectoparasites in the experimental and control group was 95.6-99.0\% and 85.1-91.1\%, respectively. The blood tests showed that hematological and biochemical parameters were within physiological norms for both groups. Also, a pharmacokinetic study was performed on 18 ISA cross, 40-day-old chickens administered orally with the test drug at the same dose. The results revealed that ivermectin reached maximum concentration at 30-60 minutes after administration to the bird. After 1 hour, the concentration of the active substance of the drug in the blood serum of chickens decreased sharply and reached the limit of quantification by 12-24 hours. In conclusion, this drug can be recommended for use in poultry as an effective and safe drug for the treatment of arachnoentomosis in birds.
\end{abstract}

Key words: Chickens, Ectoparasites, Ivermectin.

\section{INTRODUCTION}

Prevention measures of infectious diseases are carried out in clearly prescribed terms and a certain sequence as a rule in industrial poultry farms (Limarenko et al., 2005). Unfortunately, little attention is paid to the treatment of infectious diseases. Most often it is necessary to deal with the consequences of these diseases, which leads to additional economic losses (Arisov et al., 2014).

Generally, adult chickens are kept on the floor, not in the cage, in modern poultry farms in Russia. This fact can lead to infection with ectoparasites including ticks, fleas, and biting lice, which can be found in poultry farms with different production technologies (Limarenko et al., 2005). Usually, chickens are infected with Dermanyssus gallinae, Argas persicus, Epidermoptes bilobatus, Knemidocoptes species, Citodies ticks, Menopon gallinae, and fleas (Nagornaya, 2015; Safiullin et al., 2015; Sigognault Flochlay et al., 2017). A large number of these parasites in birds lead to a decrease in egg production, loss of body weight and, often, death. Also, ticks are carriers of borreliosis, ornithosis, cholera, and plague (Safiullin et al., 2012). The broad-spectrum antiparasitic, including ivermectin-based drugs, are used to treat ectoparasites in chickens (Melnis, 2016; Nagornaya, 2016; Zubarev et al., 2016). Ivermectin (22,23-dihydroavermectin B1), consisting of the main component of 22,23-dihydroavermectin B1a and the minor component of 22,23-dihydroavermectin B1b, is one of the most active compounds of the avermectin series (Chhaiya et al., 2012). Most of the well-known drugs based on ivermectin are toxic and have a long elimination period and can accumulate in organs and tissues of animals, thus, are difficult to be applied widely in production (Semeryak, 2009).

Many manufacturers of ivermectin-containing drugs use excipients in a certain ratio and concentration, thereby contributing to the formation of a stable complex with the active substance, which enters the target organs and bypasses the undesired organs (Abramov et al., 2014). For example, an antiparasitic drug for farm animals includes ivermectin, 
vitamin $\mathrm{E}$ and organic solvents, which provide the formation of a stable complex of ivermectin with a prolonged duration of action. It also increases the resistance of the host organism, prevents local reactions and toxicity (Nepoklonova and Prokhorova, 2013).

The aim of the present study was to study the prevalence of ectoparasites in a poultry farm and the efficacy of an ivermectin-based drug with a new component composition of excipients against ectoparasites in broiler chickens.

\section{MATERIALS AND METHODS}

\section{Ethical approval}

This study used the most humane and operational methods and manipulations to prevent pain and distress in birds. All painful manipulations were carried out in compliance with regulatory standards of the European Convention for the Protection of Vertebrate Animals Used for Experimental and other Scientific Purposes (ETS 123), Directive 2010/63/EU on the protection of animals used for scientific purposes.

\section{The test drugs}

The work included a test drug that consists of active substance ivermectin and the following auxiliary substances: diethylene glycol monoethyl ether (DEME), Tween-80, benzyl alcohol, jojoba Resplanta, and purified water. Jojoba Resplanta (Res Pharma Industriale, Italy) is a composition of jojoba oil, glycereth-8 ether, and water, representing a nonionizable water-soluble colloidal complex. This drug is a solution for oral administration.

\section{Study of the pharmacokinetics of ivermectin}

A total of 18 ISA cross chickens at the age of 40 days, weighing 2.0-2.2 kg, were selected for the study of the pharmacokinetics of ivermectin in the body of birds. Generally, three experimental groups of six animals each were formed from chickens. All chickens were weighed before drug administration to accurately dose the chickens.

The birds were kept in the poultry farm of Pavlovskaya Poultry Factory LLC, Nizhny Novgorod Region, Russia. The birds were monitored by veterinary specialists before and during the experiment. The birds were clinically healthy and no abnormal physiological state was noted. The test drug was administered to the birds once individually orally with water at a dose of $0.04 \mathrm{ml}$ of the drug per $1 \mathrm{~kg}$ of body weight, which corresponds to $400 \mu \mathrm{g}$ of ivermectin per $1 \mathrm{~kg}$ of body weight. Blood sampling was carried out before administration of the drug, as well as in the different times after single oral administration (first group: after $0.75,3,24$; the second group: $0.25,2,6,12$; the third group: $0.5,1,9$ hour s post-drug administration). Blood was collected in polyethylene tubes without anticoagulant and serum was separated by centrifugation. Samples were delivered in a thermocontainer to the laboratory of MNITs OZOS LLC and placed in a freezer $\left(-25^{\circ} \mathrm{C}\right)$ until the analysis.

\section{Determination of ivermectin in serum}

The technique is based on the determination of ivermectin by high-performance liquid chromatography with precolumn modification with $\mathrm{N}$-methylimidazole and trifluoroacetic anhydride and subsequent detection by fluorescence (MUK, 2009). Quantitative determination was carried out using the internal standard method. To calculate the concentrations of ivermectin in the blood serum samples, the equations obtained for the trend line of the calibration graphs for extracts of model samples of biomatrixes were used:

$\mathrm{CIVE}=(\mathrm{SIVE} / \mathrm{SIS}-\mathrm{b}) / \mathrm{k}$

Where: CIVE is the desired concentration of ivermectin in serum, $\mathrm{ng} / \mathrm{ml}$; SIS is peak area of doramectin (internal standard), $\mathrm{mV} * \mathrm{sec}$; SIVE is peak area of ivermectin in the sample extract, $\mathrm{mV} * \mathrm{sec} ; \mathrm{k}$ and $\mathrm{b}$ are coefficient of the calibration dependence.

\section{Experimental groups}

The experiment was conducted on 1,200 Highsex Brown chickens (1 to 1.5-year-old) to determine the prevalence of ectoparasites. Twenty chickens were selected and divided into two groups (experimental and control) of 10 birds each according to the principle of analogs. The experimental group was administered the prepared ivermectin-based drug at a dose of $0.4 \mathrm{ml} / \mathrm{L}$ of drinking water $(400 \mu \mathrm{g}$ ivermectin per $1 \mathrm{~kg}$ of bird weight), twice with a 24-hour interval. The treatment was repeated one more time after 14 days. To prepare a treatment solution of the test drug in a single dose, calculated on the treated number of birds, it was diluted $1 / 4$ in daily consumed drinking water. The control group was administered another drug-based on ivermectin in the same dose and manner as the drug tested in the experimental group.

\section{Diagnosis of ectoparasites}

The diagnosis of ectoparasites in chickens was established based on examination of the bird's body (ticks are visible to the naked eye) before and after treatment. Ticks were collected by the sweeping method using a brush on a 
white sheet of paper. The collected material was preserved in $70 \%$ alcohol. Further, the species of insects were determined using a light microscope (eyepiece 10, field lens $\times 40$ ), and according to the practicum on the diagnosis of infectious animal diseases (Akbaev et al., 2006) and the determinant of Mallophaga in domestic animals (Blagoveshchensky, 1940). The treatment efficacy was evaluated by the number of parasites in the experimental and control group ratio before and after treatment, expressed as a percentage.

\section{Clinical observation and blood sampling}

The birds were observed from the 1 st to 28 th day of the experiment and changes in the bird's clinical condition were recorded. Blood sampling was performed before the start of the experiment and immediately on day 28 of the experiment. On the night before blood sampling, the bird was not fed to prevent the results distortion. Access to the water was not limited. Blood was collected in tubes coated with K3-EDTA anticoagulant for the general analysis. Blood smears were stained according to the Romanowsky-Giemsa method. Stained smears were examined under immersion magnification on a trinocular digital microscope. For the analysis of biochemical parameters, blood was collected in test tubes without an anticoagulant, centrifuged after coagulation at 3,000 rpm for 3-5 minutes to obtain serum (Voronin et al., 2006).

\section{Statistical analysis}

Statistical analysis was performed using SAS/Stat software, version 9 (SAS Institute Inc., USA). Differences were considered to be significant at $\mathrm{p}$-value $<0.05$.

\section{RESULTS AND DISCUSSION}

Ectoparasites were found on the body of birds, litter, and crevices. The results of entomological studies of all chickens before drug administration showed that birds were infected with the following ectoparasites: D. gallinae (12.0\%), M. stramineus $(34.5 \%)$, and M. gallinae $(21.5 \%)$. Biting louse M. stramineus was found on the chest, thighs and around the cloaca. The skin of birds was pale, with areas of irritation and the presence of scabs. Ruffled plumage, anxiety, bites on affected areas, and a decrease in appetite and body weight were observed in chickens infested with biting louse $M$. gallinae. In cases of infestation with $D$. gallinae an untidy and dull plumage, as well as weight loss, were observed. The results of the evaluation of the efficacy of the ivermectin-based drugs are presented in Table 1.

The number of parasites/chicken after treatment compared to before treatment decreased significantly $(p<0.05)$ in both the experimental and control groups. The efficacy of the test drug against ectoparasites in the experimental group was 95.6-99.0\%. The effectiveness of another drug-based on ivermectin was 85.1-91.1\%. Also, the results showed that the number of parasites/chicken after treatment between the experimental and the control group was significantly different $(\mathrm{p}<0.05)$.

During the study, no negative effect of the drugs on the physiological state of birds was detected. No side effects and complications were noted. Hematological and biochemical parameters of blood were within physiological norms (Table 2). Hematological parameters in the experimental and the control group were slightly different $(\mathrm{p}>0.05)$.

Dermanissiosis and malophagosis cause significant economic damage to poultry farms (Safiullin et al., 2012). There is a narrow spectrum of insecticides containing ivermectin to treat these parasitosis at the pharmaceutical market of Russian manufacturers. One of these drugs is an experimentally tested medicinal product (Neomek, "Ecoprom", Russia), which is a solution for oral use. This form is a convenient and less costly way to mass-treat birds at poultry farms and private farmsteads. The significant feature of the drug composition is the presence of an emulsifier, a jojoba Resplanta with a high content of vitamin E and a complex mixture of unsaturated essential fatty acids, which is chemically resistant (Arya and Khan, 2016). Fatty acids with ivermectin form a complex that enters the skin depot. Ivermectin is secreted gradually through the pores on the skin surface and has a prolonged antiparasitic effect. Vitamin E is a natural antioxidant, which can reduce the toxic effect, eliminate immunosuppression and unwanted side effects of the drug. The use of jojoba Resplanta in the drug composition as an auxiliary component helps to increase the bioavailability of ivermectin. According to the pharmacokinetic study of the drug, ivermectin was detected in all chickens 15 minutes after a single oral administration, reaching its maximum after 30-60 minutes. The maximum concentrations of ivermectin in the blood of chickens ranged from 145.5 to $182.7 \mathrm{ng} / \mathrm{ml}$. The concentration of ivermectin decreased by more than 2 times by 2-3 hours. After 1 hour, the concentration of the active substance of the drug in the blood sera of chickens decreased sharply and reached the limit of quantification by 12-24 hours. Ivermectin is rapidly absorbed after oral administration and is also rapidly excreted from the systemic circulation, as can be seen from the data presented. Ivermectin can also accumulate in organs and tissues due to its lipophilic properties, this fact leads to a prolonged antiparasitic effect (Moreno et al., 2015).

The drugs used in the experimental and control groups had the same active substance (ivermectin), but different auxiliary components. The prepared ivermectin-based drug administered to the experimental group contained jojoba Resplanta. The drugs were administered through drinking water at a dose of $400 \mu \mathrm{g}$ ivermectin per $1 \mathrm{~kg}$ of body weight, twice with a 24-hour interval. The treatment was repeated one more time after 14 days. Data are expressed as mean \pm 
standard deviation. Means in the same row are slightly different ( $\mathrm{p}>0.05)$. AST: Aspartate aminotransferase, ALT: Alanine aminotransferase (Lineva, 2003; Nasonov et al., 2014).

The results of the present study in the treatment of ectoparasites are consistent with data from other researchers (Abramov et al., 2014; Melnis, 2016; Xu et al., 2018). The efficacy of the tested drug was slightly higher compared to other drugs based on ivermectin. Abramov et al. (2014) revealed that the drug Ivermek (active substance: ivermectin) for oral administration was highly effective against M. stramineus, M. gallinae, Dermatoryktes mutans, and Aphaniptera spp. Melnis (2016) investigated the efficacy of another ivermectin-based drug (Iversan) at the therapeutic dose of 1 $\mathrm{ml} / 10 \mathrm{~L}$ of water once and at the same dose twice (with 24-hour interval) and reported $76 \%$ efficacy against D. gallinae. $\mathrm{Xu}$ et al. (2018) reported that the effectiveness of an oral dose of ivermectin at $5.0 \mathrm{mg} / \mathrm{kg}$ body weight of chickens against $D$. gallinae was $71.32 \%$. Therefore, the pharmaceutical interaction of the certain ratio of components of the test drug increased the efficacy of the drug on the treatment of arachnoentomosis in birds and minimized adverse reactions and complications.

Table 1. The results of treatment of broiler chickens with ivermectin-based drugs against ectoparasites

\begin{tabular}{|c|c|c|c|c|c|c|c|}
\hline \multirow{3}{*}{ Species } & \multicolumn{4}{|c|}{ Number of parasites/chicken } & \multirow{2}{*}{\multicolumn{2}{|c|}{ Treatment efficacy $(\%)$}} & \multirow{3}{*}{$\begin{array}{c}\text { Reliability of } \\
\text { treatment }^{1}\end{array}$} \\
\hline & \multicolumn{2}{|c|}{ Before treatment } & \multicolumn{2}{|c|}{14 days after the last treatment } & & & \\
\hline & $\begin{array}{l}\text { Experimental } \\
\text { group }(n=10)\end{array}$ & $\begin{array}{c}\text { Control group } \\
(n=10)\end{array}$ & $\begin{array}{l}\text { Experimental } \\
\text { group }(n=10)\end{array}$ & $\begin{array}{c}\text { Control group } \\
(\mathbf{n}=10)\end{array}$ & $\begin{array}{l}\text { Experimental } \\
\text { group }(n=10)\end{array}$ & $\begin{array}{c}\text { Control group } \\
(n=10)\end{array}$ & \\
\hline $\begin{array}{l}\text { Dermanyssus } \\
\text { gallinae }\end{array}$ & $20.30 \pm 5.40$ & $20.10 \pm 4.20$ & $0.90 \pm 0.74$ & $3.00 \pm 0.67$ & 95.6 & 85.1 & $\mathrm{p}<0.05$ \\
\hline $\begin{array}{l}\text { Menacanthus } \\
\text { stramineus }\end{array}$ & $62.40 \pm 9.30$ & $63.20 \pm 8.10$ & $0.60 \pm 0.51$ & $5.70 \pm 0.67$ & 99.0 & 91.1 & $\mathrm{p}<0.05$ \\
\hline $\begin{array}{l}\text { Menopon } \\
\text { gallinae }\end{array}$ & $51.60 \pm 4.80$ & $52.40 \pm 3.80$ & $1.20 \pm 1.10$ & $6.60 \pm 1.30$ & 97.7 & 87.4 & $\mathrm{p}<0.05$ \\
\hline
\end{tabular}

The drugs used in experimental and control groups had the same active substance (ivermectin), but different auxiliary components. The prepared ivermectin-based drug administered to the experimental group contained jojoba Resplanta. The drugs were administered through drinking water at a dose of $400 \mu \mathrm{g}$ ivermectin per $1 \mathrm{~kg}$ of body weight, twice with a 24 -hour interval. The treatment was repeated one more time after 14 days. Data are expressed as mean \pm standard deviation. ${ }^{1}$ Reliability of treatment for experimental and control groups (before and after treatment)

Table 2. Hematological and biochemical blood parameters of broiler chickens infected with ectoparasites at 14 days after the last treatment with ivermectin-based drugs

\begin{tabular}{lccc}
\hline \multirow{2}{*}{ Parameters } & \multicolumn{2}{c}{ Chicken group } & \multirow{2}{*}{ Normal range } \\
\cline { 2 - 3 } & Experimental group $(\mathbf{n = 1 0})$ & Control group $(\mathbf{n = 1 0})$ & $38-42$ \\
\hline Hematocrit $(\%)$ & $40.89 \pm 1.48$ & $41.86 \pm 1.93$ & $3.0-4.0$ \\
Red blood cells $\left(10^{12} / \mathrm{L}\right)$ & $2.96 \pm 0.13$ & $3.03 \pm 0.10$ & $80-120$ \\
Hemoglobin $(\mathrm{g} / \mathrm{L})$ & $108.40 \pm 2.66$ & $107.30 \pm 3.93$ & $32-100$ \\
Platelets $\left(10^{9} / \mathrm{L}\right)$ & $58.40 \pm 2.70$ & $56.40 \pm 4.15$ & $20-40$ \\
White blood cells $\left(10^{9} / \mathrm{L}\right)$ & $20.13 \pm 1.85$ & $21.41 \pm 2.39$ & $30-60$ \\
Total protein $(\mathrm{g} / \%)$ & $31.50 \pm 1.55$ & $30.60 \pm 1.59$ & $119-892$ \\
Uric acid (mmol/L) & $255.30 \pm 8.46$ & $252.20 \pm 10.89$ & $300-500$ \\
Alkaline phosphatase (u/L) & $443.00 \pm 42.83$ & $400.70 \pm 25.40$ & $107-481$ \\
AST (u/L) & $232.40 \pm 10.80$ & $235.90 \pm 5.97$ & $13-23$ \\
ALT (u/L) & $16.30 \pm 2.13$ & $15.20 \pm 2.26$ & \\
\hline
\end{tabular}

\section{CONCLUSIONS}

The study demonstrated that the used ivermectin-based drug had a high efficacy (95.6-99\%) in the treatment of arachnoentomosis and no side effects and drug complications in chickens were seen. Thus, this drug can be recommended for use in poultry farms as an effective and safe drug for the treatment of arachnoentomosis in birds.

\section{DECLARATIONS}

\section{Acknowledgments}

Thanks to the staff of Closed joint-stock company "Scientific-production firm "Ekoprom".

\section{Competing interests}

No conflict of interest exists.

\section{Funding}

This study was supported by All-Russian Scientific Research Institute of Fundamental and Applied Parasitology of Animals and Plants (ARSRIP). It was also conducted within the State Assignment to ARSRIP. 


\section{REFERENCES}

Abramov VE, Arkhipov IA, Koshevarov NI, Kidyaev VI, Morozov AB, Napalkov VV and Safarov MI (2014). The effectiveness of the Ivermek drug against ectoparasites of birds. Poultry Farming, 5: 41-45. Available at: https://www.elibrary.ru/download/elibrary_21845819_42317330.pdf.

Akbaev MSh, Vasilevich FI, Menshikov VG, Akbaev RM, Shustrova MV and Davydova OE (2006). A practicum on the diagnosis of infectious animal diseases. Koloss, Moscow, p. 536.

Arisov MV, Indyukhova EN and Stepanov AA (2014). Use of the Insectal Spray product in chickens with mallophagoses in the poultry house of the detached house. Veterinary, livestock and biotechnology, 11: 6-9. Available at: https://www.elibrary.ru/item.asp?id=22747715.

Arya D and Khan S (2016). A Review of Simmondsia chinensis (jojoba) "the desert gold": A multipurpose oil seed crop for industrial uses. Journal of Pharmaceutical Sciences and $8(6)$ Research, $381 . \quad$ Available at: https://pdfs.semanticscholar.org/3af2/2b707eaec4d07560f0741fcfb6fc6c8643ec.pdf.

Blagoveshchensky DI (1940). The determinant of Mallophaga in domestic animals. The fauna of the USSR, new series N 27. Publishing House Academy of Sciences of the USSR, p. $346 . \quad$ Available https://www.directmedia.ru/book 114612 Fauna SSSR_Opredelitel_pukhoedov_Mallophaga_domashnikh_zhivotnykh/.

Chhaiya SB, Mehta DS and Kataria BC (2012). Ivermectin: pharmacology and therapeutic applications. International Journal of Basic \& Clinical Pharmacology,1:132-9.DOI: https://doi.org/10.5455/2319-2003.ijbcp002712.

Limarenko AA, Dubrov IS, Taymasukov AA and Zabashta SN (2005). Diseases of Agricultural Birds: a Handbook. Lan, S.Petersburg,p. 448. Available at: Direct Link

Lineva A (2003). Physiological Indicators of the Norm of Animals. Aquarium LTD., Moscow; Federal state unitary publishing and polygraphic enterprise "VYATKA", Kirov, p. 256.Available at: https://www.livelib.ru/book/1000375932/about-fiziologicheskie-pokazateli-normy-zhivotnyhlineva-a

Melnis RI (2016). Evaluation of the efficacy of the Iversan product with nematodoses and chicken dermanissiosis. Theory and Practice of the Parasite Animal Diseases, 17: 248-252. Available at: https://cyberleninka.ru/article/n/otsenka-effektivnosti-preparata-iversan-pri-nematodozah-idermanissioze-kur/viewer.

Moreno L, Dominguez P, Farias C, Canton L, Virkel G, Mate L, Ceballos L, Lanusse CE and Alvares L (2015). Ivermectin pharmacokinetics, metabolism, and tissues/egg residue profiles in laying hens. Journal of Agricultural and Food Chemistry, 63(47): 10327-10332. Available at: https://pubs.acs.org/doi/abs/10.1021/acs.jafc.5b04632.

MUK 4.1.1874-04 (2009). Determination of the mass concentration of ivermectin in organs and tissues, plasma and milk of animals treated with iversect using fluorescence high-performance liquid chromatography. Federal Center for Hygiene and Epidemiology of Rospotrebnadzor, Moscow, p. 8. Available at: http://docs.cntd.ru/document/1200081326

Nagornaya LV (2015). Features of therapeutic and preventive measures for quail dermansisiosis. Scientific Bulletin of the Lviv National University of Veterinary Medicine and Biotechnology named after S.Z. Gzhitsky, 17(62): 154-159. Available at: https://cyberleninka.ru/article/n/osobennostilechebno-profilakticheskih-meropriyatiy-pri-dermaniscioze-perepelov.

Nagornaya IV (2016). The effect of insecticidal treatments with ivermectin products with mallophagoses on the clinical status of chicken blood. Scientific notes of the Educational Institution "Vitebsk Order of the Badge of Honor, the State Academy of Veterinary Medicine", 52(2): 60-63. Available at: https://e.lanbook.com/journal/issue/300034.

Nasonov IV, Buiko NV, Lizun RP, Volykhina VE, Zakharik NV and Yakubovskiy SM (2014). Methodological recommendations on hematology and biochemical studies in chickens of modern crosses.Minsk, p. 32. Available at: https://docplayer.ru/69619927-Metodicheskie-rekomendacii-pogematologicheskim-i-biohimicheskim-issledovaniyam-u-kur-sovremennyh-krossov.html

Nepoklonova IV and Prokhorova IA (2013). Antiparasitic agent for farm animals. Patent RU2013114434/15A from 04/01/2013. Available at: https://patents.google.com/patent/RU2519085C1/ru.

Safiullin RT, Bondarenko LA and Vavilov Yu S (2015). Epizootological situation on chicken mites and the efficacy of the Biorex-GH product in production experience. Russian Parasitological Journal, 2: 83-91. DOI: https://doi.org/10.12737/11777.

Safiullin RT, Murzakov RR and Bondarenko AA (2012). Efficiency of Drucker 10. 2 against chicken mite with outdoor maintenance of young stock of hens of egg breed. Theory and Practice of Parasitic Animal Diseases, 13: 376-380. Available at: https://cyberleninka.ru/article/n/effektivnostdrakera-10-2-protiv-kurinogo-klescha-pri-napolnom-soderzhanii-remontnogo-molodnyaka-kur-yaichnoy-porody.

Semeryak EV (2009). Pathomorphological signs of toxicity and the long-term effects of ivermectin on the animal organism. The dissertation of the candidate of veterinary sciences, Omsk, p. 164. Available at: https://www.dissercat.com/content/patomorfologicheskie-priznaki-toksichnosti-iotdalennye-effekty-deistviya-ivermektina-na-org

Sigognault Flochlay A, Thomas E and Sparagano O (2017). Poultry red mite (Dermanyssus gallinae) infestation: a broad impact parasitological disease that still remains a significant challenge for the egg-laying industry in Europe. Parasites and Vectors, 10:357. DOI: https://doi.org/10.1186/s13071-017-2292-4.

Voronin ES, Snoz GV, Vasilyev MF, Kovalev SP, Cherkasova VI, Shabanov AM and Schukin MV (2006). Clinical diagnosis with radiology. Koloss, Moscow: p. 509.Available at: http://booksshare.net/index.php?id1=4\&category=biol\&author=voronin-es\&book=2006.

Xu X, Wang C, Zhang S, Huang Y, Pan T, Wang B and Pan B (2019). Acaricidal efficacy of orally administered macrocyclic lactones against poultry red mites (Dermanyssus gallinae) on chicks and their impacts on mite reproduction and blood-meal digestion. Parasites and Vectors, 12(1): 345. Available at: https://parasitesandvectors.biomedcentral.com/articles/10.1186/s13071-019-3599-0

Zubarev VN, Kashkovskaya LM and Safarova MI (2016). An effective regimen to combat red chicken mites. Poultry Farming, 6: 51-53. Available at: https://www.elibrary.ru/download/elibrary 26206881_30724007.pdf 